Article

\title{
The Role of Environmentally Conscious Architecture and Planning As Components of Future National Development Plans in Egypt
}

\author{
Karim M. Ayyad ${ }^{1, *}$ and Mostafa Gabr ${ }^{2}$ \\ 1 Department of Architecture, Modern Sciences and Arts University, 6th of October City 12564, \\ Egypt; E-Mail: karim.ayyad@yahoo.com \\ 2 Department of Construction and Architectural Engineering, American University in Cairo, \\ Cairo 11835, Egypt; E-Mail: m.gabr@aucegypt.edu \\ * Author to whom correspondence should be addressed; E-Mail: karim.ayyad@ yahoo.com; \\ Tel.: +20-100-999-1089; Fax: +20-383-71-543.
}

Received: 7 September 2013; in revised form: 30 September 2013 / Accepted: 6 October 2013 / Published: 14 October 2013

\begin{abstract}
Egypt has been experiencing challenging economic, social and political disturbance during the end of the twentieth century and towards the beginning of the twenty-first. With its fast expanding population, high consumption rate and economic deficit, the Egyptian community continues to experience a low quality of living. These issues contributed greatly to the uprising, following the Tunisian model, in January, 2011. However, the political change that followed did not help a lot, as development strategies are still far from being sustainable. In the beginning of the millennium, Egypt experienced an $8.6 \%$ energy deficit, followed by a growing energy crisis [1]. Knowing that almost 50\% of the energy produced in Egypt is consumed inside buildings [2], environmentally conscious architecture can be a very powerful tool in development plans, as it can reasonably reduce the consumption of energy and other resources and enhance the quality of living for people. This work analyzes the supposed role of environmentally conscious architecture and, hence, evaluates its importance as a major component of national development plans in the near future. The analysis encompasses a review of the status quo in terms of consumption patterns and required services and, then, compares it with the case in which environmentally conscious architecture is adopted.
\end{abstract}

Keywords: environment; consumption; energy; resources; Egypt; development 


\section{Introduction to Development and Building in Egypt}

Egyptians live on about $7.7 \%$ only of Egypt's total land area [3]. The rest is a mere desert. Those five percent are mainly the Nile Valley, where most agriculture, urbanism and the population of 91 million people [3] are concentrated. Another issue is the concentration of services in the main cities, such as Cairo, Alexandria and Giza, leading to the immigration of citizens from the countryside to these cities, which have a better quality of life and services, causing over-population and stress on resources. The greater Cairo metropolitan area is home to around 12 million people, according to a 2013 estimate [3]. The new immigrants usually cannot afford living in the expensive neighborhoods of the city, preferring to create informal settlements, which are usually on agricultural land. The phenomenon having been there for decades, the portion of the population of Cairo living in slums reached about 56\% in 1996 [4]. Houses in those areas are usually built at a minimum cost, neglecting most aesthetic, hygienic and environmental aspects. On the other hand, luxurious settlements and condominiums are built around main cities to be home to an also evolving high-income class. Those settlements usually have fancy villas, massive green areas, artificial lakes and, sometimes, golf courses. However, these compounds are rarely sustainable, as they consume a lot of water for the irrigation of turf in a very arid climate and form a burden on the country's electricity grid.

In rural areas, especially in the Nile Delta, villages suffer from a very high population density. As a result, villagers started building their houses using reinforced concrete, instead of the recyclable clay blocks that have been used in villages since ancient times. Reinforced concrete allows them to build for or five-story houses to accommodate their growing families. The expanding concrete villages now are destroying large areas of agricultural land, together with cities, at the rate of $0.56 \%$ a year [5].

Although Egypt's industry is performing well, industrial areas are usually situated around big cities and the Nile Delta in order to be near the main consumption spots, leading to high pollution levels. The low quality of public transportation has also stimulated the use of private cars, reaching to about 5.8 million cars in Egypt in 2010 [6].

With the aforementioned issues and the expected climate change and SLR (sea level rise), living conditions in Egypt in the coming decades could get much worse. Therefore, it is apparent that development schemes in Egypt are not sustainable and that the huge urban expansion and most building patterns do not follow proper design methodologies. Dismal as this fact could be, it also opens the door for further studies and elaboration on how to have a "green" national development plan. In the next points, this process is tackled, through analyzing the history of development and its current status and discussing how environmentally conscious architecture and planning can have a role in future development plans.

\section{History of Development and Building Strategies in Egypt}

Since Egypt is a country with a long history, it has a legacy of development strategies that can be useful to look at before suggesting new ones. The following points shed some light on selected development and building strategies through Egypt's history. 


\subsection{Ancient Egyptians: Understanding the Environment}

When desertification eradicated most of the forest, ancient Egyptian tribes descended from the two plateaus in the eastern and western deserts to the fertile Nile Valley to begin a civilization based on agriculture around $3500 \mathrm{BC}$ [1]. However, they never built cities or villages directly on the banks of the Nile. The lands along the river were used as croplands, as they are flooded with water and nutritive sedimentations every year. Cities were usually built on the eastern plateau on relatively elevated land, while the western plateau was dedicated entirely for tombs, such as pyramids and "mastabas". The good understanding for the environment that ancient Egyptians had was also obvious in the materials used for building, as secular buildings, like houses and even the Pharaohs' palaces, were built using recyclable clay blocks, while tombs and temples were built with durable limestone to last for thousands of years. The ancients also built water channels and aqueducts to enhance agricultural production. They have also dug a channel connecting the Nile with the Red Sea to facilitate trade. Thus, it is generally correct to say that Ancient Egyptians had an excellent understanding of the environment and its different elements and learned how to make sustainable use of them.

\subsection{Islamic City and Architecture}

Cities during the Islamic era, starting from the seventh century and mainly maturing in the 10th century, were designed with a high appreciation of environmental factors. Knowing that Egypt's climate is mainly hot arid, streets were narrow in order to provide shade for pedestrians, street markets were often sheltered and houses were built with various features that help ease the harsh weather. Examples of these feature are: inner courtyards with gardens and fountains, wind-catchers, shokhshekhas_octagonal wooden covers of the ceiling, which allow movement of the air within a covered space-mashrabeyas_-wooden protruding windows with detailed wooden lattices (see Figure 1) — and others. Special schemes were utilized in home designs in order to create air current, shade and a friendly internal environment. Islamic architecture in Egypt also had a high sense of using local materials in building, ranging from limestone for walls of palaces and fortifications, mud bricks for peasant houses, wood for Arabesque art in furniture and decorations and marble for flooring and fountains. The architects and urban planners of the era joined their ancient Egyptian predecessors and avoided building communities right on the banks of the river. All three seeds of what is now Cairo were built during the Islamic era; Al-Fustat, Al-Qatai'e and Al-Qahira were not on the bank of the Nile. Regarding nationwide projects, the Arabs have also re-dug the channel that connected the Nile with the Red Sea [7] and dug several aqueducts and channels to improve irrigation.

\subsection{The Era of Royalty: Mohamed Ali's Descendants}

After independence from the Ottoman Empire, Mohamed Ali and his descendants founded modern Egypt. However, during their reign (1805-1953), they tried to imitate the European model of civilization rather than improving the Egyptian one. Architecture and planning were greatly influenced by Ottoman and European styles. Thus, little attention was given to understanding the Egyptian environmental profile and responding to it. Khedive Ismail, in particular, re-planned modern Cairo following the model of Paris, where he received his education, recruiting several European 
architects [8]. Although Egypt was rich at that time, there was a huge gap between the rich elite and the very poor villagers who lead a lifestyle that was not much different from their ancient Egyptian ancestors. They dwelled in mud-brick houses with no access to safe drinking water or proper sanitation. Development was focused on maximizing agricultural production and services only. Urban development was focused on enhancing existing cities rather than founding new ones as the population growth was slow. Nationwide development projects were not aimed at improving the average citizen's quality of life. Instead, they were built in favor of the monarchy, their allies and the rich elite. For example, Mohamed Ali's aqueducts in Qalyubia north of Cairo, which were started in 1843 and completed in 1868, mostly benefited the wealthy class that owned most of the croplands of the Nile Delta at that time. Furthermore, the Suez Canal, which was built mostly by forced Egyptian workers in 10 years (1859-1869) [9], was shared property and under the control of France and, later, Great Britain. Therefore, there was hardly any development that was environmentally conscious or people-oriented in Egypt during that era.

Figure 1. Wooden mashrabeyas in Old Cairene house (author).

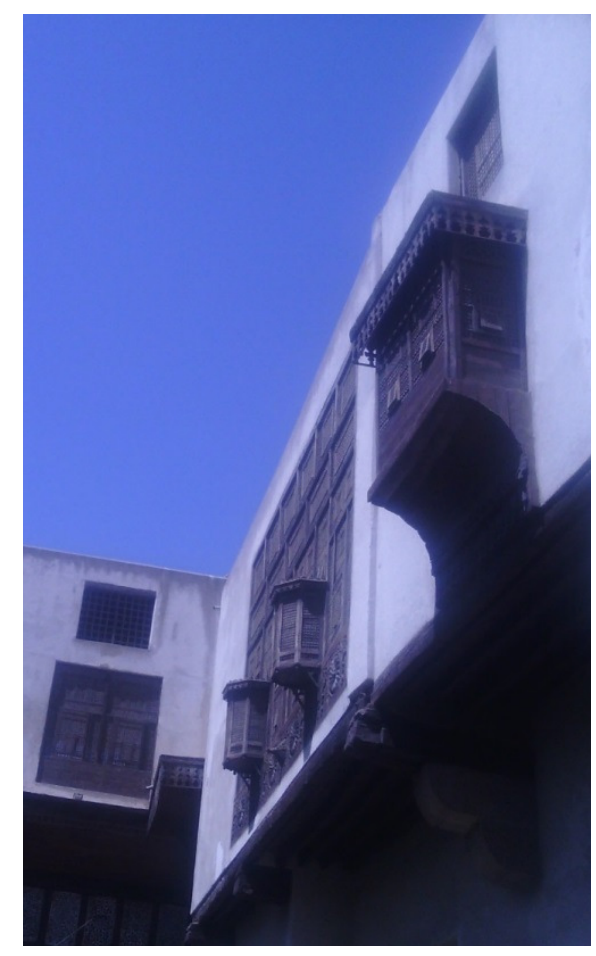

\subsection{Development between Socialism and Capitalism}

On 23 July 1952, a military-led revolution supported by the Egyptian people ousted Kind Farouq I, and in 1953, a constitutional republic was declared. In the beginning, Mohamed Naguib, the highest officer in the "Free Officers" movement that led the movement, was president, but then, Gamal Abdel-Nasser, widely known as Colonel Nasser, became president in 1953. Nasser's government embraced socialism and had very wide cooperation with the USSR. His government redistributed wealth, by seizing land and big corporations from the rich elite and publicizing them or reassigning their ownership to poorer classes. The government inaugurated massive projects in the fields of industry, energy and agriculture. An improvement in industrial and agricultural production occurred 
after the completion of the Aswan High Dam south of Egypt in 1970 [10], as it provided power and a constant water flow for irrigation. Regarding urban development and housing, the government started numerous projects of housing for the poorer people, constructing standard apartment buildings in the main cities and renting the apartments to citizens at low prices. In the beginning of this era, the people of Egypt could reap the fruits of this development, as they received shares of the country's wealth and the political situation was relatively stable. However, starting from the mid-sixties, the quality of life declined again, due to various reasons, such as the hostility between Nasser and Western economic forces, large-scale economic and military aid to emerging Arab states and increased military spending due to the war with Israel after the latter occupied the Sinai Peninsula in 1967.

During Sadat's presidency period (1970-1981), socialism slowly left the scene as the new president adopted a more market-oriented economic policy. After the 1973 war with Israel and having achieved

a political victory, Sadat reformed the economy. He created economic ties with the United States and Europe, allowing foreign investment to flow into the country. However, his economic reform program was not always welcomed by the people. In 1977, wide demonstrations and violence erupted in the country after the government cancelled subsidies to a big number of basic goods, forcing Sadat to cancel the decision [11]. In terms of housing, his government also continued to provide housing for middle and low-income classes and even transferred the ownership of apartments that the government had been renting to its dwellers.

Having its political system changed from a monarchy ending in 1952 to a constitutional republic, economic policy changed from capitalism to strict socialism and, then, to a socio-capitalism, and having gone into war three times $(1956,1967,1973)$ in a period just over 29 years, Egypt has relatively achieved reasonable development with respect to the circumstances. However, this development cannot be tagged as sustainable, as the government policy was always leaning towards realizing development projects that showed fast benefits for the people without looking at the long-run consequences. An example of this fact is the construction of the Aswan High Dam, which changed the river's ecosystem, as it barred nutritive sedimentation, which naturally fertilizes agricultural land and helps to stop the erosion of the coast of the river delta by the sea. Another example was the construction of industrial areas around big cities, without understanding the future expansion of those cities, making those industrial areas too close to some parts of those cities nowadays and causing high pollution and safety issues for millions of citizens. At the same time, the high population growth rate was not carefully studied or dealt with by the consecutive governments, causing a huge leap in population that was not matched by a similar economic growth. Thus, the overall analysis of this period shows some development, but it was hardly sustainable or environmentally conscious.

\subsection{Capitalism and Corruption}

Assuming power in 1981, Mubarak's ruling years (1981-2011) were more into foreign cooperation and stimulating private businesses as an approach for development [12]. His peace-keeping strategy also helped stabilize the economy and bring in foreign investment. However, starting from the 2000s, intensified corruption elevated as wealthy businessmen cooperated with the ruling party (National Democratic Party) to manipulate the markets of almost all goods and industries. In the construction market, for example, EZ-DK (Al-Ezz Al-Dekheila Steel Industries), the main provider of reinforcing 
steel - the lifeblood of the construction sector-and owned by Ahmed Ezz, the secretary general of the NDP (National Democratic Party) — controlled 66\% of the market after merging his business with a number of government companies [13]. This process of 'privatization' received a lot of criticism as hundreds of government-owned enterprises and industries were sold to foreign and local investors, while many of them were well-performing businesses. Very few government projects benefited the average citizen, as the gap between the rich and the poor widened. In 2011, 25\% of the Egyptian population lived below the poverty line [14], as prices kept going up. Regarding housing and urban development, the government provided some housing solutions for youth and newly married couples, but for prices that most of them could not afford. In 1997, the government started a huge project in Toshka, south of the Aswan High Dam, aiming at using part of Nasser's lake to irrigate new agricultural lands west of the Nile. Promising as the government media labeled it, the project never returned any tangible benefits to the average citizen nor helped slow down the sky-rocketing food prices. In fact, the project was intended to make use of the water already getting spilt from the Toshka natural spillway in Nasser Lake rather than creating a feasible agricultural project [15]. As a result of these circumstances, public rage slowly increased, until it erupted in January, 2011, in a quest for real development that could enhance the quality of living of the average Egyptian.

\subsection{Pursuit of Democracy and Development}

While the world watched the January 2011, uprising against Mubarak's regime with admiration, the massive event was fueled by much suffering that the people had been through for decades, due to the lack of proper development and the disappearance of many of the citizens' rights. The motto being chanted in all of Egypt's squares and streets was "Bread, Freedom and Social Equity!" It was clear after six decades of the declaration of the republic that proper development without peace, transparency and democracy is almost impossible. Although the first two years following the ouster of Mubarak's regime were accompanied by economic decline, the Egyptian people still hope that the newly-born democracy can bring sound development to the country. However, it is important that any development strategy learn from the lessons of the past and adopt sustainability principles in order to achieve long-lasting development for the people of Egypt.

\section{Status Quo: Development at Crisis}

Having analyzed the history of development strategies throughout most of Egypt's history, this section tackles a number of issues that have been creating hurdles for development plans and decreasing the quality of life for the average citizen since the beginning of the last decade and up to present time. The issues are analyzed from a sustainable point of view in order to take them into consideration while formulating a more sustainable development plan for the future.

\subsection{Population Growth}

Population burst, as the government media calls it, has been a challenge for development in Egypt for decades. With an average fertility rate of 3.1 children per adult female per year, the population increases by about 2.0\% annually [16]. According to 2013 estimates, the population of Egypt has 
reached 91 million [3]. Being a mostly desert country with only 7.7\% of the country inhabited [3], the large population has put pressure on the country's limited resources. This issue increases the severity of all of the points discussed below; poverty, food production deficit, water shortages and energy crises. It is also a direct cause of the informal expansion of urban areas at the expense of croplands in many parts of the Nile valley. Although the government strategy to combat population burst in the last decade has succeeded in lowering the population growth rate to just $2.0 \%$ per year, the added population every year might still be large in comparison with the declining economy.

\subsection{Poverty}

As of 2011, 25\% of the Egyptian population lived below the poverty line [14]. Diminishing living quality was one of the main reasons for the 2011 uprising that was followed by a lot of hope for political and economic reform. However, political unrest, which is still on the scene in Egypt, has hurt the economy even more. With much less foreign investment and a slowing down in most businesses, the government used a big part of its monetary reserves. As of 31 March 2013, net monetary reserves held by the Central Bank of Egypt were USD 13.4 billion compared to USD 36 billion in early 2011, due to a widening trade deficit and the continued decline in revenues from tourism and foreign direct investments [17]. Knowing that between September 2012, and April 2013, the Egyptian pound lost $11 \%$ of its value to the US dollar (from USD 1 selling at EGP 6.08 to 6.8) - and hence, increasing prices in local markets-despite easing prices globally, it is obvious that economic decline is already on the scene. Therefore, poverty patterns are not expected to improve in the near future unless a quick economic reform plan is adopted.

The rapid increase in governmental corruption and social injustice has been affecting Egypt in the last few decades. This has led to the poverty that directly affects the people. Although education is almost free in government school, many have not continued their education or have an education that is not of a high standard. This lapse in education has affected the environmental consciousness of people and unintentionally transferred the belief that caring about the environment is a matter of luxurious welfare and of secondary importance, although it is the only way to a better life. Furthermore, rapidly searching for income has made Egyptians more closed off and concerned for themselves, not caring about the surrounding environment, as that is not giving them the better life that everyone is searching for.

\subsection{Food Production Deficit}

In its 2007 assessment [18], the IPCC (Intergovernmental Panel on Climate Change) declared the Nile Delta one of three sites on Earth that are most vulnerable to sea level rise (SLR). The results indicate that about $22.49 \%$ of the total area of the coastal governorates of the Nile Delta would be susceptible to inundation under different scenarios with an SLR of $1 \mathrm{~m}$ as shown in Figure 2, 42.18\% with an SLR of $1.5 \mathrm{~m}$ and 49.22\% with an SLR of $2 \mathrm{~m}$ [18]. The Nile Delta is responsible for about $40 \%$ of Egypt's food production [19]. The drowning of $20 \%$ of it under seawater means a mere eight percent shortage in food production by 2050. At the same time, urban expansion decreases agricultural land in the Nile valley by an average of $0.54 \%$ per year. After 40 years, this could destroy up to $20 \%$ of agricultural land. As a result, by 2050 , decline in yields due to climate change is expected 
to reach $28 \%$ for soybean, $18 \%$ for wheat and barley, $19 \%$ for maize and sorghum and $11 \%$ for rice [20]. The food production deficit will trigger more food imports, which already reached $40 \%$ of consumed food in 2010 and $60 \%$ of wheat [21].

With already soaring food prices, Egyptians may not be able to afford more imported food. The government may have to continue subsidizing some food products, which may lead to further economic crises.

Figure 2. The effect of a sea level rise (SLR) of $1 \mathrm{~m}$ on Egypt's north coast and Nile Delta [22].

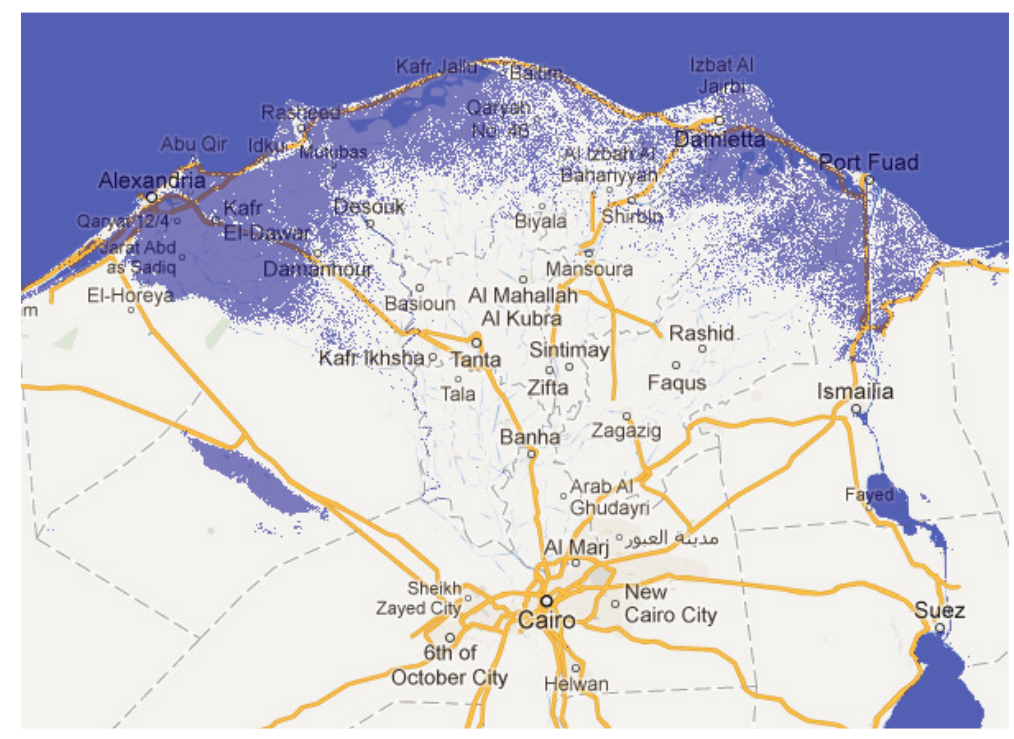

\subsection{Water Shortages}

While some studies foresee an increase in Nile water by $25 \%$ over current yearly levels, others anticipate decreases up to 70\% [23]. Moreover, the new Nile Basin Initiative signed by seven Nile-basin nations may reduce Egypt's share in river water, which is currently $66 \%$ of total water revenues [24]. Knowing that Egypt currently uses its entire share [25], a water crisis could be imminent in the next decade. The combination of these factors have put Egypt in eighth place on the list of the top ten countries at risk of water shortages, by Global Research, Canada [24].

\subsection{Energy Crisis}

Since the beginning of 2012, the inhabitants of almost all parts of Egypt experienced blackouts more often than usual. In summer, 2013, the government announced that blackouts were distributed fairly upon the country's cities and districts, with a rate of 1-2 $\mathrm{h}$ per day [26]. This is due to the hike in demand of electric current that occurs in summer due to the increased use of air conditioners and electric fans. Moreover, there is a gap between electricity generation and consumption that makes an $8.6 \%$ deficit [1], which is expected to reach $20 \%$ in 2025. Moreover, shortages in petroleum products has occurred several times since 2011 to date, causing queued vehicles to accumulate waiting for fuel outside gas stations in almost all parts of the country [26]. While the government announced that the crises were due to the smuggling of subsidized petroleum products to the black market, many analysts argued that the fuel was used to run electricity stations to help decrease the shortage in the electricity supply. 
It is clear that the issues mentioned above are the consequences of non-sustainable and environmentally unaware strategies of development that have been adopted in Egypt for decades. The country's development has been leaning towards the consumption of resources with the least cost on the government, but was unaware of the cost on the environment and the renewability of resources.

\section{Potential for Applying Environmentally Conscious Architecture in Egypt}

This section discusses some selected points that can support the application of environmentally conscious architecture and planning in Egypt.

\subsection{The Need for Lowering Consumption}

Knowing that architecture controls how people interact with the environment and the way they use its resources, there are so many things that environmentally-conscious architecture can do to help decrease consumption. This is because environmentally-conscious architects do their best to understand the environment and its driving forces and learn how to use this to allocate peoples' needs in a way that does not harm the chances of coming generations to allocate theirs, too. However, the main stream in developing countries, like Egypt, goes for fast development rather than a sustainable one. Most new communities are built to provide shelter for the growing population without looking at the long-term footprint of these communities on resources. In Cairo, almost 39\% of investment in real estate is directed toward informal housing [27], which usually consumes more resources, as it lacks proper design and maintenance. At the same time, luxurious compounds usually also consume many resources, such as electricity and water. Most of the compounds built in new areas around main cities boast having large areas of turf and green areas, while, in fact, they need enormous amounts of water for irrigation in such an arid climate. Therefore, there is a great demand for applying environmentally conscious architecture and planning in the housing sector, as it would save the government and private stake-holders a lot of money and effort.

\subsection{The Need for Solving the Housing vs. Agriculture Dilemma}

In a dilemma that has been around for decades, there has been a clear conflict between housing and agriculture. While cities are expanding to provide housing for an increasing population and since both cities and agriculture lie on the banks of the river, vast areas of croplands are being turned into urban areas. Although this harms the country's food security, building around existing villages and cities is usually more convenient, as it utilizes the existing infrastructure. According to Dr. Farouq El-Baz, the agricultural land shrinkage rate has reached $0.54 \%$ annually [5]. With this rate, Egypt may lose all of its croplands after 183 years [5]. New settlements and cities established in the desert outside the Nile valley help ease the phenomenon, but do not solve the conflict entirely, as apartment prices in these new settlements are relatively high. Moreover, in cities and small towns in the Nile Delta, building on croplands is the only option people are left with, since there are no new nearby cities or towns. The issue is not only a clear example of non-sustainable development strategies that have been there for decades, but also shows the great role sustainable planning can play to improve life in Egypt. With 
proper environmentally conscious planning, the future generations would find their needs for housing and quality of living without destroying the agriculture they depend on for food.

\subsection{Establishment of the Egyptian Green Building Council and the GPRS}

The EGBC (Egyptian Green Building Council) was established in January, 2009, by the Ministry of Housing, Utilities and Urban Development with the participation of the University of California, Irvine. The council has established an assessment tool called the GPRS (Green Pyramid Rating System). The GPRS provides definitive criteria by which the environmental credentials of buildings can be evaluated and the buildings themselves can be rated. The concept of green building observes important criteria, which secure the attainment of the required quality and efficiency of the buildings. It covers guidance, location preparation and careful study, consideration of optimal methods for water consumption, including recycling of used water for other industrial and agricultural purposes, studies on lighting, air conditioning, natural ventilation and renewable energy sources, such as solar and wind energy systems. It was started in 2010, and the first edition was made available for public review in April 2011. The GPRS provides four levels of certification depending on the score of the project in the weighted factors: "Certified", "Silver Pyramid", "Gold Pyramid" and the highest level of certification, "Green Pyramid" [28].

The GPRS has not been discussed or approved yet by the House of Parliament, due to the 2011 uprising and the political instability that followed it. Therefore, the system is still prone to change, and no certification has been officially awarded to any project. However, the step puts Egypt among the list of countries making efforts to systemize and support green building.

These points create a suitable atmosphere to kick-off the application of environmentally conscious architecture and planning on a wider scale in Egypt, as the country is striving for sensible development for the present generations and the coming ones.

\subsection{Already Existing Environmentally Conscious Building Attempts}

In his book "Architecture for the Poor", Hassan Fathy [29] presented a kind of architecture that is affordable and feasible for the poor. He introduced vernacular architecture as an attempt at a solution for housing with the least consumption of resources. At the same time, Fathy recognized his work, in New Gourna village near Luxor, as experimental. He knew that an experiment, by definition, can lead to what is right or wrong. Therefore, he encouraged future experimenting to develop his theories to a more applicable version. He said "I hope that [New] Gourna might just hint at a way to begin a revived tradition of building that others might later take up the experiment, extend it" [29].

Indeed, some architects extended the experiment, such as Ramses Wasef, Bahaa Bakry, Ahmad Hamed, Abdel-Halim Ibrahim and others. In their works, they tried to combine the accumulated environmental experience of vernacular architecture with the new concepts of sustainability and green design. However, their works rarely receive public appreciation, as the market forces drive it into a more industrialized concrete architecture. Recently, a private construction company has collaborated with the EGBC (Egyptian Green Building Council) to design a residential compound for the middle class that is $40 \%$ powered by renewable energy [30]. The compound is sought to be the first green residential compound by the EGBC standards. 


\section{Towards an Environmentally Conscious Development Plan in Egypt}

In order to achieve sustainable development and reach an environmentally conscious development plan in Egypt, there are crucial steps that have to be taken to solve the issues discussed in the past sections. These steps represent the physical output of the role of environmentally conscious architecture and planning as a component of future national development plans.

\subsection{Getting out of the Nile Valley}

A basic strategy for sustainable development in Egypt is to begin using the vast $95 \%$ of the country's area outside the Nile valley that hardly has any inhabitants. There have been several proposals aiming at creating new communities outside the Nile valley, such as Dr. Farouq El-Baz's "Development Corridor" project that he has been working on for almost 30 years [5]. The project is basically a new valley parallel to the existing one, stretching from Toshka to the north coast west of Alexandria. Instead of the river being the axis of development, there is a transnational highway, a natural gas pipeline, a water system and a high voltage electricity line. The project aims at creating new residential and industrial zones, leaving the fertile land of the old valley exclusively for agriculture. The project shows environmental awareness as it stimulates urban and industrial development in the western desert, while discouraging the loss of croplands to urbanism. Another project is the Qattara Depression project, which suggests digging a channel to connect the depression with the Mediterranean Sea, filling it up with seawater and turning it into a salt lake [31]. The project then suggests the establishment of new communities based on beach tourism and fishing, accommodating millions of inhabitants and providing hydro-electric and wind power. The project received much criticism, as it would cause many changes in the local environment of the north coast and parts of the Libyan Desert.

These projects and similar proposals must be studied further from an environmental point of view in order to be well evaluated. If feasible and environmentally sound, they can be very good assets to future national development plans.

\subsection{Sustainable Cities}

In the development of new communities, Egypt needs sustainable cities. Several conferences have been held in the last decade to raise awareness about the issues of sustainability and environmentally-conscious architecture. In 2010, the British University in Cairo launched an initiative and a competition called "The Egyptian Dream City" for students and professional architects to design a new sustainable city to be the future capital of Egypt [32]. In 2012, at a conference organized by Cairo University, the oldest and most prestigious university in the country, attended by the Minister of Housing, Utilities and Urban Development, efforts to turn Sheikh Zayed city into a green city were exhibited [33]. Sheikh Zayed is one of the new cities established in the desert west of Cairo. The city council issued a note requiring any new houses in the city to have solar water heating systems. Moreover, the Ministry announced that it was studying applying the same rule to all new cities and towns to be built in the future. 


\subsection{Smart Buildings}

There have been various attempts to explain what a smart or intelligent building is. These attempts were done by the Asian Institute of Intelligent Buildings (AIIB), the Building Research Establishment Ltd., the Intelligent Building Society of Korea (IBSK), the Shanghai Construction Council (SCC), the Architecture and Building Research Institute (Taiwan) and, finally, the Smart Buildings Institute (SBI) in the USA.

According to Jim Sinopoli, managing principal of Smart Buildings LLC, smart building is only smart when it has cabling infrastructure, lighting control systems, facility management tools, a work order system, preventative and predictive maintenance, material and equipment parts inventory control, asset management, data standards and building information modeling (BIM) integration. However, this definition is only capturing what is inside the building, as the building is an important help to, yet a pressure on, the surrounding environment. That is why environmental impact assessment (EIA) of buildings has emerged, to help with how any building can impact its surrounding environment. Smart buildings have shown less impact on the environment.

Smart buildings can reduce consumption and increase the building's contribution toward lessening environmental damage. In Egypt, almost 50\% of electricity consumption is inside buildings [2]. Since well-designed buildings, with the aid of available technologies, can save up to $33 \%$ of energy consumption in comparison to conventional ones, it is possible to save up to $16.67 \%$ of Egypt's electricity consumption. That would be more than the electricity generated by the Aswan High Dam.

Smart technologies in water saving and recycling can also save much of the water consumed in typical households. Knowing that $10 \%$ of Egypt's water annual consumption (around 6.7 billion $\mathrm{m}^{3}$ ) is allocated for domestic use [34], it is possible to save a huge amount of fresh water through water-saving technologies in buildings.

Smart buildings also need less maintenance and are easily recycled with respect to conventional ones. New materials can be utilized to make them safer and more environmentally friendly than reinforced concrete and red bricks, which currently dominate the construction industry in Egypt and cause skyrocketing housing prices, let alone the pollution their manufacturing causes. Therefore, smart buildings can be very beneficial to future development plans in Egypt, as they decrease consumption and the footprint of development on the environment.

\subsection{Greening the Existing}

Building new communities, cities and buildings does not mean the existing ones should be left behind. There' is a huge capital of structures that cannot be just abandoned. They will continue to be used and will still consume a lot of resources, no matter how green the new ones are. However, studies show that greening existing buildings can be very feasible in the long-run. Some researchers argue that retrofitting existing buildings can save $30 \%-50 \%$ of a building's energy consumption through the combination of energy efficiency strategies affecting multiple systems [35]. Therefore, it is also important to retrofit existing buildings with green technologies and concepts as part of future development plans. 


\section{Conclusions}

It is to be concluded from this study that environmentally conscious architecture and planning are crucial for future national development plans, as the country experiences a considerable challenge in economic, social and environmental terms. The study proved this statement by showing how the failure to comply with the environment requirements in past development plans has harmed the community and quality of life in Egypt throughout the decades. It has also shown the potential that environmentally conscious architecture and planning have through different studies that have proven the amount of resources that can be saved. Moreover, the study presented some initiatives and projects that can be of paramount importance as components of future national development plans in Egypt.

It is the hope of the authors that this work will add to the knowledge in the field of integrating environmentally conscious architecture and planning into national development plans. It is also hoped that it will reach decision-makers and advisors in Egypt and the institutions that are taking part in development there.

\section{Acknowledgments}

The authors would like to thank the late Bahaa Bakry, Ahmed Abdin and Ahmed Fekry for their contribution to the knowledge and information on which this study was based.

\section{Conflicts of Interest}

The authors declare no conflict of interest.

\section{References}

1. Saber, M. Environment in Jeopardy: Consequences of climate change in Egypt. J. Ecol. Nat. Environ. 2004, 1, 191-195.

2. Henzler, M. Study on Energy Efficiency in Public Buildings in Egypt, 2012. Available online: http://www.adelphi.de/en/projects/project_database/dok/43525.php?pid=587 (accessed on 19 June 2013).

3. Ahram Online. Egypt Population Reaches 91 Million, Grows 18 percent in Eight Years, [Online]. Al-Ahram Newspaper, 30 August 2012. Available online: http://english.ahram.org.eg/ News/51634.aspx (accessed on 30 June 2013).

4. UN-Habitat. Global Report on Human Settlements 2003, The Challenge of Slums, Part IV: "Summary of City Case Studies"; Earthscan: London, UK, 2003; pp. 195-228.

5. Baraka, H. Green Profile: Interview with Farouq El Baz. Available online: http://www.egyptindependent.com/news/green-profile-interview-farouk-al-baz (accessed on 11 June 2013).

6. Ahram Online. Egypt Vehicles up 13.5 Percent in 2010, New Figures Show, [Online]. Al-Ahram Newspaper, 4 August 2011. Available online: http://english.ahram.org.eg/NewsContent/3/12/ 18085/Business/Economy/Egypt-vehicles-up--per-cent-in-,-new-figures-show.aspx (accessed on 11 June 2013).

7. Rappoport, S. History of Egypt; The Grolier Society: London, UK, 2005; pp. 248-257. 
8. Myntti, C. Paris along the Nile: Architecture in Cairo from the Belle Epoque; American University in Cairo Press: Cairo, Egypt, 2003.

9. Wilsons, A.T. The Suez Canal; Oxford University Press: Oxford, UK, 1939; p. 54.

10. Abu-Zeid, M.A.; El-Shibini, F.Z. Egypt's high aswan dam. Water Resour. Dev. 1997, 13, 209-217.

11. Agence France-Presse (AFP). 30 Years after Bread Riots, Egypt Reform Moves forward. [Online]. Daily News Egypt, 21 January 2007, Available online: http://www.dailystaregypt.com/ article.aspx? ArticleID=5112 (accessed on 15 March 2013).

12. Perr, J. Hosni Mubarak's Economic Achievements, [Online]. Daily Finance, 10 February 2011. Available online: http://www.dailyfinance.com/2011/02/10/hosni-mubaraks-economic-achievements/ (accessed on 17 July 2013).

13. Selim, T.H. Monopoly: The case of Egyptian steel. J. Bus. Case Stud. 2006, 2, 85-91.

14. World Bank DataBank Home Page. Available online: http://databank.worldbank.org (accessed on 13 July 2013).

15. Osman, H.M. Hydro Development in Egypt: Lessons From High Aswan Dam. In Proceedings of the WCD Regional Consultation, Cairo, Egypt, 8-9 December 1999.

16. World Population Data Sheet 2012; U.S. Population Reference Bureau, 2012. Available online: http://www.prb.org/pdf12/2012-population-data-sheet_eng.pdf (accessed on 15 July 2013).

17. FAO GIEWS Country Briefs: Egypt. Available online: http://www.fao.org/giews/countrybrief/ country.jsp?code=EGY (accessed on 13 April 2013).

18. Intergovernmental Panel on Climate Change (IPCC). AR4-Climate Change 2007: Synthesis Report; IPCC: Geneva, Switzerland, 2007.

19. Vella, J. The Future of Food and Water Security in New Egypt; Future Directions International Pty Ltd.: Dalkeith, Australia, 2012.

20. Eid, M. Climate Change Studies on Egyptian Agriculture. In Proceedings of the Egypt-US Workshop on Global Climate Change, NARSS, EEAA and USEPA, Cairo, Egypt, 10-12 May 1999.

21. Salem, M.; Yassin, H. Minister: Egypt Imports 40 Percent of Its Food, [Online]. Egypt Independent, 6 August 2010. Available online: http://www.egyptindependent.com/news/ministeregypt-imports-40-its-food (accessed on 18 March 2013).

22. National Aeronautics and Space Administration (NASA). Egypt Flood. n.d. Available online: http://flood.firetree.net/?ll=30.9286,30.5370\&zoom=7\&m=1 (accessed on 11 June 2013).

23. El Quosy, D. Integrated Water Management and Farmers Participation in Egypt. In Proceeding of the IGBP Regional Workshop, MENA, Cairo, Egypt, 20-21 November 2008.

24. Global Research HomePage. Top Ten Countries at Risk of Water Shortages, 2010. Available online: http://www.globalresearch.ca/top-ten-countries-at-risk-of-water-shortages/19996 (accessed on 23 March 2013).

25. Al-Awady, S. Egypt on the World List of Poorest Countries in Water Resources, 22 March 2011. Available online: http://www.resourcecrisis.com/index.php/water/679-135 (accessed on 25 July 2013).

26. Hussein, M. Post Morsi: Egypt's Energy Woes Far from Over, [Online]. Al-Ahram Newspaper, 21 July 2013. Available online: http://english.ahram.org.eg/News/77018.aspx (accessed on 20 July 2013). 
27. Sims, D. Residential Informality in Greater Cairo: Typologies, Representative Areas, Quantification, Valuation, and Causal Factors. Master's Thesis, Institute for Liberty and Democracy, Lima, Peru; Egyptian Center for Economic Studies, Cairo, Egypt, 2000.

28. Egyptian Green Building Council Official Website. Available online: http://www.egypt-gbc.gov.eg/ (accessed on 24 July 2013).

29. Fathy, H. Architecture for the Poor; The University of Chicago Press: Chicago, IL, USA, 1973.

30. Aqarmap Website Florenta El-Maadi. Available online: http://aqarmap.com/eg/en/compounds/ details/cairo/174/florenta (accessed on 18 July 2013).

31. Weisensee, P.; Ragheb, M. Integrated Wind and Solar Qattara Depression Project With Pumped Storage as Part of Desertec. In Proceedings of the RETBE'12 9th International Conference, Alexandria, Egypt, 22-24 December 2012.

32. Bakry, W. The Dream City: The First Architectural Competition towards Getting out of the Valley, [Online]. Al-Masry Al-Youm Newspaper, 27 September 2011. Available online: http://www.almasryalyoum.com/node/500049 (accessed on 23 June 2013).

33. Hassan, A. Sheikh Zayed City Council Celebrates "Green City", [Online]. Al-Youm Al-Sabea Newspaper, 7 February 2013. Available online: http://www.youm7.com/News.asp?NewsID=937786 (accessed on 11 June 2013).

34. Abdin, A.E.; Gaafar, I. Rational Water Use in Egypt. In Technological Perspectives for Rational Use of Water Resources in the Mediterranean Region; The International Centre for Advanced Mediterranean Agronomic Studies (CIHEAM): Bari, Italy, 2009.

35. Davis, J. Energy-Saving Deep Retrofits, [Online]. Urban Land Institute, 14 June 2012. Available online: http://urbanland.uli.org/Articles/2012/April/ul/DavisEnergy (accessed on 11 June 2013).

(C) 2013 by the authors; licensee MDPI, Basel, Switzerland. This article is an open access article distributed under the terms and conditions of the Creative Commons Attribution license (http://creativecommons.org/licenses/by/3.0/). 